\title{
Genesis of Polio Vaccination Hindrance Syndrome in Pakistani Society, Religio-Medical Aspects
}

\author{
Sadia Fida Ullah', Farzana Ahmad Deen ${ }^{2}$, Yawar Hussain ${ }^{3}$ \\ ${ }^{1}$ Institute of Biological Sciences, University of Brasilia, Brasilia, Brazil \\ ${ }^{2}$ Independent Researcher, Gujranwala, Pakistan \\ ${ }^{3}$ Department of Civil and Environmental Engineering, University of Brasilia, Brasilia, Brazil \\ Email: yawar.pgn@gmail.com
}

Received 9 February 2016; accepted 14 March 2016; published 17 March 2016

Copyright (C) 2016 by authors and Scientific Research Publishing Inc.

This work is licensed under the Creative Commons Attribution International License (CC BY). http://creativecommons.org/licenses/by/4.0/

(c) (i) Open Access

\begin{abstract}
Polio vaccination in Pakistan has received strong reaction from the society. Many reasons have been documented in literature to explain the causes of this issue. The present study is focused on the analysis of anatomy of genesis of Polio Vaccination Hindrance Syndrome (PVHS) in the light of Quranic Verses, Hadiths (saying of Prophet) and their interpretations done by the Muslim clerics at weekly sermons (Khotbat). Along with religious explanation, the medical aspects of vaccination are also taken under consideration. It is concluded from this analysis that Islam does not resist from Polio Vaccination and related medication. The real problem lies in the perception of vaccination as an attempt to genocide Muslims, coupled with lack of interests in international agencies.
\end{abstract}

\section{Keywords}

Hadiths, Khotbat, Islam, Pakistan, Polio Vaccination

\section{Introduction}

The confusions created by the contradictory results at laboratories and interpretations of sources of Islamic laws at Mosques have deprived the Pakistani children from the provisions of basic health facilities. According to World Health Organization (WHO) 2015 survey report, there are 58 documented polio cases in Pakistan, which are $85.2 \%$ of the total worldwide reported cases of Polio [1]. But the accuracy of this survey is questionable in the northern parts of the country [2]. The ambiguity about the failure of achievement of Global Polio Eradication Goals in Pakistan has remained unsolved in minds of many people [3]. Major among the proposed causes of this 
menace are Military-Talban Nexus [4], State Imposed Religion, Biomedical and religious Illiteracies, Lack of Trust in US [5] and extremist factions versus innocents.

Pakistan is theocratic state which is emerged on world map in the name of Islam [6]. Since then its society remained dominated by the clerics, particularly rural areas of Khyber Pakhtunkhwa (KPK) and Federally Administered Tribal Areas (FATA). These clerics deliver speeches on Friday, termed as Jummah Khutba (Friday Sermons). During these speeches, they explain their own version of world affairs. Similarly, this class of religious clerics lacks scientific knowledge, however further circumstances are worsened by the neglect of national security agencies to curb the menace of preaching anti-state and anti-Islam thinking.

Another important aspect of this issue which is being highlighted in this study is the safety of clan through continuous family growth. In Pakistani society family is an important social institution, which is considered to be a social strength, economic source and of political significance. An attempt aiming at casting harm to this institute will receive stronger reaction from society. State actors in Pakistan take their strength from family and its growth is encouraged at all levels. In recent times a threat to family was perceived by the society in the form of polio vaccination which was encountered in the form of development of "Hindrance Syndrome" in society against polio vaccination. This Syndrome is characterized as a concurrent set of both emotions and actions (http://www.merriam-webster.com/dictionary) of symptoms of Polio vaccination avoidance. A rumor spread throughout the sub-continent (Pakistan, India); that vaccination is an attempt to sterile people, in order to solve the problem of overgrowing population in these regions [7]. This problem has become even worse in Pakistan because of the lack of trust in Americans. It is a common perception among Pakistanis that America is against the Muslim world and wants to destroy it [8]. This perception was strengthen by repeatedly and continuous issue of fatwas from both local Mullahs and Imam Khamenei's ideological enmity against US and medical reports which showed their suspicions [9] and even some had proved the presence of hormones in polio vaccine [10]. Polio vaccination considered as a part of American stratagem in terms of sterility of Muslim population and resulted one major factor in the failure of polio immunization programs in Pakistan [11].

The present study is focused on the analysis of the perception of vaccination as an attempt to genocide Muslims and coupled with lack of interests in international agencies. The medical aspects of Polio vaccination are also being discussed.

\section{Material and Methods}

All three sources of Islamic Medical Jurisprudence (primary, secondary and tertiary) are taken under consideration in this analysis. Reading of Tanka, Al-Quran, and Books of Al-Hadith and other related history books. Listening to the claims of Mullah (clerics) made in their Khutbat at Friday prayers. The questionnaires based survey related to attitude of different levels of society towards vaccination, which was conducted by [12] is used as a source of secondary data. Google database, related literature reviews, national and international newspaper articles covering this topic remained the focus of consideration during all phases of this article formulation.

\section{Results and Discussion}

\subsection{Religious Aspects}

Vaccine controversies in Nigeria, India and Pakistan may have taken their roots from religion believes and cultural practices [13]. Suspicions about polio vaccine has polarized the religious people into two groups as pro-vaccine and anti-vaccine. Both groups follow Quran and Hadith, but their perceptions of effects of vaccination on Muslims population are different. Pro-vaccination group has supported this campaign on the basis of their perception as life savior, healthy Muslim race while anti-vaccination groups have perceived it as a threat to Muslim population through human hormonal polluted polio vaccine. Both groups gave references to Islamic medical jurisprudence and medical proves which best describe their perceptions.

It was claimed that Polio vaccination was a part of a sinister US plan to decrease the Muslim population in the world [14]. It was propagated that Polio vaccination leads to impotency. Conservative and illiterate Mullah (clerics) of Federally Administered Tribal Areas (FATA) and Khyber Pakhtunkhwa (KPK) had announced in 2007 that polio vaccination is an infidel campaign [15] to weaken Muslim strength through birth control [16]. There are many Fatwas of Haram (prohibited), which are based on following three reasons; Deflection of will of God, Trypsin is Pork driven (Porcine origin), Vaccination belongs to Kuf'far (Non-Muslims). Muslims believed; 
that Will of God is involved behind suffering. Every child's fate has been written before his birth. On the basis of this believe; vaccination is considered as an attempt to deflect the will of Allah, while the theology of Islam is something else. The analysis of sole trusted and only book indicates (Al-Quran) "There is a cure for every disease. Whenever an illness is treated with its right remedy, it will be cured by the will of Allah” (Muslim Kitab us Salam Hadith 4048). Vaccine a life savior; and Allah the primary source of Islamic law says, "and if any saved a life, it would be as if he has saved mankind” (Al-Ma'idah, 5:32). There are many other Ahadith (sayings of Prophet), which supports the use of Polio vaccination in terms of disease medication for healthy and stronger Muslim race, which are well described in reference to their link with polio vaccination by [17]. Enzyme trypsin (protease enzyme) used in the oral polio vaccine (OPV) has infuriated Muslims, because the source of its extractionis pork. Pork eating is strongly prohibited in Islam because of dirtiness [18]. Trypsin is used to dissociate the virus from cell culture. Trypsin quantity is minute and it istotally washed out in the final product, this fact still sparked rumors that the vaccine is Haram, or prohibited. According to the Quran; a person is not guilty of sin in a situation where the lack of a halal alternative creates an undesired necessity to consume that which is otherwise Haram (Al-Baqra2:173). Trypsin is clearly permissible, according to the Islamic principle Hizb-ul-waqiyasup-posing that trypsin is unclean, it is thoroughly filtered, that it leaves no traces whatsoever in the final vaccine [19].

There is another irrigational objection on polio vaccine is that it is Haram because this vaccine belongs to non-Muslim countries, no reference in the Quran or Hadith prohibits seeking a cure from a non-Muslim. The Prophet Mohammad himself sent for Al-Harith Ibn Kulda, the doctor of the Arabs, for medical advice, who was a Jew [20].

Since the time of separationist movement led by Muslim League Mosque has played a dominant role in opinion formation among the people. The role of Mosque in genesis of this syndrome can never be overlooked. The Imams (priest) at Mosque are usually uneducated person, they have no knowledge of science and technology and other social sciences. They are not trained well even in religious aspects as well. Their interpretations of current issues are usually old. All of their interpretations are derived from some common concepts as, Indian and Americans hatred, gender discrimination, sectarianism and anti-progressive thoughts. They usually explain all events in light of these concepts. Some of clerics even claimed that it is un-Islamic to vaccinate their children and those who die of Polio are martyrs [21]. Pro-vaccination groups have even supported this campaign at Mosques Khutbat (speeches) as Life savior, Healthy younger Muslim nations and deceased free society by use of Hormones free polio vaccination from international agencies. They even joined polio vaccination team at door to door campaign in Afghan immigrant community at Lahore [22].

\subsection{Vaccination Teams}

In 1990's Government of Pakistan with the collaboration of United Nations launched a country wide population control campaign. The major objectives of this campaign was to control population by spreading awareness among the people at country wide network of Green Start Centers. They provided the masses with contraceptive measures and pills. State used its administrative machinery including media campaigns in the opinion formation of the people. The benefit of having a small family was addressed. So, the crux of the matter is that the polio vaccination has been channelized by the same department which strengthened the previously existed vaccination hindrance syndrome among the people.

The involvement of polio vaccination team in assassination of Bin-Laden has further aggravated the situation, this involvement has triggered the wrath of Taliban's on this issue [23]. In response to aforementioned reasons, several cases of kidnappings and violating of polio vaccinators have been reported [24]. In 2003, vaccination campaigns have also been hampered by Islamic extremists, in Afghanistan especially in the Nigeria [25]. Furthermore, a recent mistake made by the law enforcement agencies in Pakistan, which started a brutal campaign to arrest the parents who refused to vaccinate their children against polio [26].

\subsection{Medical Aspects}

This conspiracy about birth control attain more attention, when the security protocol analyzed the polio vaccine contaminated with human hormones, these hearsays added another excuse against vaccination with its major theological concerns. The Polio (poliomyelitis) is a disease caused by Polio virus [27], this virus enters through mouth and multiply in gastrointestinal tract [28], and from here it moves with blood stream to central nervous 
system [29] and attacks the motor neurons which are responsible for arms and legs movement. Polio virus is highly contagious. The common modes of its transmission are fecal-oral and oral-oral. The high risk factor is considered in the people, living in areas where water supply is limited [30] and people living with infected person. Our immune system provides immunity by producing the antibodies to fight against germs. Children younger than age of five and pregnant women attacked easily by this virus because of weak immune system.

But viruses have an edge to utilize the host cell metabolic machinery, so body fails to detect the virus as a foreign invader. Here vaccines plays its role. Vaccine contains attenuated or dead viruses (these viruses unable to affect your health, but able to boost up your immune system whichinturn produces antibody against viruses). Once the antibodies are so produced they stay there for the rest of your life, antibodies have strong memory, to remember the pathoffight against these viruses. Whenever the polio virus (not vaccine) enters in human body, the immune/defense system recognize it and neutralize it. For the preparation of vaccine a large number of viruses are required, these viruses are cultured on cell medium for growth (multiply in number). Removal of these viruses from cell culture require a negligible amount of trypsin (protease enzyme), which makes this whole procedure controversial for the Muslims and Jews because of its porcine origin. The function of trypsin is only to remove the virus from cell culture, later these isolated viruses properly washed to remove the traces of trypsin in the final product [31].

While if we discuss the issue of man sterility, vaccines are checked (medically) thoroughly before use, there is no prove, about contaminated vaccine have ever been administered. The Director of "National Control Laboratory of Biological” (NCLB) Pakistan, Abdul Samad Khan certified that the samples were tested for the detection of human hormones but none of six hormones was detected in the samples not even in minute quantities [32]. If we consider there is estrogen or progesterone, as Oral Polio Vaccine dose is two drops only in this minute quantity it's impossible to render the child sterility. In august 2015 Dr. Ngare's the Kenyan catholic doctor reports indicated the presence of human hormones in two out of six vaccines [10]. These vaccines were shipped and manufactured in an Indian institute. These two contradictory statements mentioned in this article, and many more similar reports and articles about contamination of polio vaccinehas polluted human minds with such ambiguities and ultimately made the vaccine unreliable. Google database showed some articles that indicates, polio vaccines contain human hormones that can hinder the child sterility. Different studied were carried out to test the polio vaccination for the presence of human hormones. A research which was carried out by [33] has scientifically analyzed the non-hormonal compounds act as anti-fertility agent in animal and human and pregnancy can be terminated by estrogen.

Children are considered as social strength, economic power, for state they severs as fuel for war, for political parties their importance is signified in terms of votes. More voters in family increase their political influence and respect in society. The problem in Muslim world is not about the use of vaccine and related polio eradication, the real problem has taken its routes in lack of trust in US and Western world. The Muslims have perceived it as a treat to their biological strength, which will gradually but surely leads to their complete extinction.

\section{Conclusion}

To conclude, the reluctance towards Polio vaccines is endemic in the Muslim world. The factors popping up the malady of Polio are many, such as biased approach towards the US lead health programs due to its interventionist policies in the past, a wave of ambiguities spread by interest groups which transformed this humanistic cause into a bon. The Islamic religious injunctions can be seen as an anti-thesis to socially constructed hatred towards medicinal Polio vaccine. In this sense, Muslims, who do reject the prophylactic in reality, disobey God and theology with which Islam supports life. Polio is one of those disastrous challenges which have badly affected least developed countries of the world. There is a need of paradigm shift and revising social narratives. Thus, strongest actions should be taken, on part of the government to kill the monster of Polio and resolve this conundrum. There is a dire need to develop an action oriented and workable mechanism. State should regularize the activities, recruitments and dealings regarding religious seminaries.

\section{References}

[1] Khan, M.U., Ahmad, A., Aqeel, T., Akbar, N., Salman, S. and Idress, J. (2015) A Cross-Sectional Survey of Healthcare Workers on the Knowledge and Attitudes towards Polio Vaccination in Pakistan. PloS One, 10, e0142485. http://dx.doi.org/10.1371/journal.pone.0142485 
[2] Farag, N.H., Wadood, M.Z., Safdar, R.M., Ahmed, N., Hamdi, S., Tangermann, R.H. and Ehrhardt, D. (2015) Progress toward Poliomyelitis Eradication-Pakistan, January 2014-September 2015. MMWR. Morbidity and Mortality Weekly Report, 64, 1271. http://dx.doi.org/10.15585/mmwr.mm6445a4

[3] Obregón, R., Chitnis, K., Morry, C., Feek, W., Bates, J., Galway, M. and Ogden, E. (2009) Achieving Polio Eradication: A Review of Health Communication Evidence and Lessons Learned in India and Pakistan. Bulletin of the World Health Organization, 87, 624-630. http://dx.doi.org/10.2471/BLT.08.060863

[4] Animesh, R. (2014) The Pakistani Taliban's Campaign against Polio Vaccination. Combating Terrorism Centre. https://www.ctc.usma.edu/posts/the-pakistani-talibans-campaign-against-polio-vaccination

[5] Park, J.Z. and Smith, C. (2000) To Whom Much Has Been Given: Religious Capital and Community Voluntarism among Churchgoing Protestants. Journal for the Scientific Study of Religion, 39, 272-286. http://dx.doi.org/10.1111/0021-8294.00023

[6] Stepan, A.C. (2000) Religion, Democracy, and the “Twin Tolerations”. Journal of Democracy, 11, 37-57.

[7] Grim, B.J. and Karim, M.S. (2011) The Future of the Global Muslim Population: Projections for 2010-2030. Pew Research Center, Washington DC. http://www.pewforum.org/2011/01/27/the-future-of-the-global-muslim-population/

[8] Hussain, R.S., McGarvey, S.T. and Fruzzetti, L.M. (2015) Partition and Poliomyelitis: An Investigation of the Polio Disparity Affecting Muslims during India’s Eradication Program. PloS One, 10, 0115628. http://dx.doi.org/10.1371/journal.pone.0115628

[9] Yahaya, M. (2005) Polio Vaccines Difficult to Swallow. The Story of a Controversy in Northern Nigeria. Institute of Development Studies. http://www.ids.ac.uk/IDS/KNOTS/PDFs/VaccYahyaNigeria.pdf

[10] Botha, L.C. (2015) Polio Vaccines Laced with Sterilizing Hormone Discovered in Kenya, Who Is Controlling Population Health Impact News.

[11] Warraich, H.J. (2009) Religious Opposition to Polio Vaccination. Emerging Infectious Diseases, 15, 978. http://dx.doi.org/10.3201/eid1506.090087

[12] Qidwai, W., Ali, S.S. and Ayub, S. (2007) Knowledge, Attitude and Practice Regarding Immunization among Family Practice Patients. Journal of Dow University of Health Sciences, 1, 15-19.

[13] Reals, T. (2006) Muslim Clerics Join India’s Polio Fight. http://www.cbsnews.com/stories/\%202006/11/13/health/main2174959.shtml

[14] Manchanda, R. (2015) Religious Dogmatism a Case of Pakistani’s Anti-Polio Vaccination Drive. Indian Opines. http://indiaopines.com/religious-dogmatism-pakistan-anti-polio-vaccination

[15] Lorenz, C. and Khalid, M. (2012) Influencing Factors on Vaccination Uptake in Pakistan. Journal of Pakistan Medical Association, 62, 59-61.

[16] Hameed, S. (2007) Infidel Vaccine: Polio Vaccination Controversy in Pakistan. http://sciencereligionnews.blogspot.com/2007/02/infidel-vaccine\%20poliovaccination.html

[17] Ebrahim, A.F.M. (2014) Vaccination in the Context of Al-Maqasid Al-Shariah (Objectives of Divine Law) and Islamic Medical Jurisprudence. Arabian Journal of Business and Management Review (Oman Chapter), 3, 44-52.

[18] Hurris, M., (1974) Cows, Pigs, Wars and Witches: The Riddles of Culture. Random House, Inc., New York.

[19] Nordin, M.M. (2013) The Permissibility of Rotavirus Vaccines—A Personal Perspective. Bangladesh Journal of Medical Science, 12, 344-345. http://dx.doi.org/10.3329/bjms.v12i4.16657

[20] Asadulla, A. (2009) Islam vs West Fact or Fiction. A Brief Historical, Political, Theological, Philosophical, and Psychological Perspective. iUniverse, Bloomington.

[21] Lorenz, C. (2013) Informal Taxation Systems-Zakat and Ushr in Pakistan as Example for the Relevance of Parallel/Semi-Public Dues (No. 51138). University Library of Munich, Germany.

[22] Messinger, R. (2015) Faith-Based Organizations and Health Care: Invest, Don’t Proselytize. The Lancet, 386, 17331733. http://dx.doi.org/10.1016/S0140-6736(15)00688-1

[23] Mark, M. (2011) Vaccination Ruse Used in Pursuit of Bin Laden. New York Times.

[24] Ahmed, Q.A., Nishtar, S. and Memish, Z.A. (2013) Poliomyelitis in Pakistan: Time for the Muslim World to Step in. The Lancet, 381, 1521-1523. http://dx.doi.org/10.1016/S0140-6736(13)60764-3

[25] Kapp, C. (2003) Surge in Polio Spreads Alarm in Northern Nigeria. The Lancet, 362, 1631. http://dx.doi.org/10.1016/s0140-6736(03)14826-x

[26] Hussain, S.A., Menezes, R.G. and Nagaraja, S.B. (2015) Parents in Pakistan Arrested for Polio Vaccine Refusal: A Necessary Step. The Lancet, 385, 1509. http://dx.doi.org/10.1016/S0140-6736(15)60751-6

[27] Modlin, J.F. (2009) Poliovirus. In: Mandell, G.L., Bennett, J.E. and Dolin, R., Eds., Principles and Practice of Infectious Diseases, 7th Edition, Chapter 171, Elsevier Churchill Livingstone, Philadelphia. 
[28] Bodian, D. (1955) Emerging Concept of Poliomyelitis Infection. Science, 122, 105-108. http://dx.doi.org/10.1126/science.122.3159.105

[29] Ohry, A., Brooks, M.E. and Rozin, R. (1978) Is the Polio Virus Responsible for Late Central Nervous System Tumors? Medical Hypotheses, 4, 44-49. http://dx.doi.org/10.1016/0306-9877(78)90027-0

[30] Nathanson, N. and Kew, O.M. (2010) From Emergence to Eradication: The Epidemiology of Poliomyelitis Deconstructed. American Journal of Epidemiology, 172, 1213-1229. http://dx.doi.org/10.1093/aje/kwq320

[31] Global Polio Eradication Initiative and World Health Organization (2003) Global Polio Eradication Initiative: Strategic plan 2004-2008.

[32] Junaid, I. (2015) Lab Tests Show Polio Vaccine Is Not “Haram”. The Dawn. http://www.dawn.com/news/1156931

[33] Lerner, L.J. Galliani, G. Carminati, P. and Mosca M.C. (1975) Anti-Fertility Drugs: Novel Non-Hormonal Compounds that Inhibit Prostaglandin Metabolism. Nature, 256, 130-132. 